


\title{
THE EFFECTS OF HERBS ON MILK YIELD AND MILK QUALITY OF MASTITIS DAIRY COW
}

\author{
E. Nurdin' ${ }^{1}$, T. Amelia ${ }^{2}$ and M. Makin ${ }^{3}$ \\ ${ }^{1}$ Faculty of Animal Science, Andalas University, \\ Kampus Unand Limau Manis, Padang 25163 - Indonesia \\ ${ }^{2}$ Faculty of Pharmacy, Andalas University, \\ Kampus Unand Limau Manis, Padang 25163 - Indonesia \\ ${ }^{3}$ Faculty of Animal Science, Padjadjaran University, \\ Jl. Raya Bandung Sumedang KM 21, Jatinangor, Sumedang 45363 - Indonesia \\ Corresponding E-mail: ellyza_n@yahoo.com
}

Received December 28, 2010; Accepted May 23, 2011

\begin{abstract}
This experiment aimed to observe the effect of herbs (Black Cumin,Curcuma zeodharia,Curcuma mangga, and Curcuma aeruginosa) supplementation on milk yield and milk quality (milk fat, milk protein, milk lactosa and mastitis status) in lactating dairy cows suffering mastitis. Twenty cows in $2^{\text {nd }}-$ $4^{\text {th }}$ lactation suspected mastitis subclinical $(++)$ were used in the experiment. Completely randomized design was used in this experiment with 5 treatments (A. Non Herb; B. Black Cumin; C. Curcuma zeodharia; D. Curcuma mangga, and E. Curcuma aeruginosa) with four replicates per treatment. The collected data were analyzed by analysis of variance and difference between the treatment effects was tested by using Duncan's Multiple Range Test. The results showed that supplementation of herbs significantly increased $(\mathrm{P}<0.01)$ milk yield, milk protein, milk lactosa and significantly decreased mastitis status and did not significant affect milk fat.
\end{abstract}

Keywords: herbs, mastitis, milk yield, milk quality

\section{INTRODUCTION}

The milk production is the main expected purpose from dairy catlle. Milk quality is important criteria for determining health and marketability of milk. Milk production in Indonesia was not in accordance with the consumer demand, because of milk ability of cow has not reached optimum point and quality of milk is poor. Factors contributing to low production include feed (quality and quantity), improper milking procedure, cage system, sanitary program and diseases especially mastitis (Sudarwanto et al., 2006).

In 2003 population of dairy cattle in Indonesia was 368,470 cows producing 577,5 tons of milk per year. Milk yield per cow per day is 6.5-8.5 litres. This is almost half of the ideal production of dairy cattle with condition of Indonesia (14-16 litres per day).

In Indonesia, the prevalence of bovine mastitis is very high as $75-83 \%$ and caused many losses, for subclinical mastitis is associated with milk 10\%-40\% reduction in milk production
(Sudarwanto et al., 2006). Minimum standard of milk quality in Indonesia was milk fat percentage is $3 \%$, milk protein percentage is $2.7 \%$ and milk lactosa is $4.1 \%$ (SNI, 1998).

The healing of the parenchymal tissue of mammary glands in mastitis animals can be attempted by antibiotics (local and parenterial), actually that mastitis condition were to overcome with body's immune response (Gravert, 1987). Usually medical treatment for mastitis is injection of antibiotics from intramammary but control of milk which containt antibiotic residues was very difficult. This effort had increasing the opportunity that there is antibiotic residue in livestock products and it will produce a metabolic substance in the body. It would endanger the public health. Frequently, antibiotic has not been used in accordance with the applicable rules. Besides that, to control of milk, which contain antibiotic residues is very difficult (Barton and Hart, 2001; Owens et al., 2001).

Another alternative to increase body defence was supplementation of herbs which have antioxidant and anti-inflammation character. Herb 
plants have been used by many people especially in Indonesia and generally in Asia. The herbs have been used in a long time by many people to overcome the inflammation that occurs in humans. The benefit of herb is affordability, ready accessibility and safe for health. Ethnoveterinary medicine refers to people's beliefs, knowledge, skills and practices relating to care of their farm (Martin et al., 2001; and Li and Ziang, 2004 ). Most of the research on testing of ethnoveterinary medicine preparations has so far been carried out in Asia. Conversely, a little number of publications has been produced that relate to diseases that affect humans and livestock (Lacobellis et al., 2005).

Several type of herbs plant such as Black Cumin, Curcuma zeodharia,Curcuma mangga, and Curcuma aeruginosa are used in Indonesian traditional medicine to increase endurance (Nurdin and Arief, 2009; Nurdin, 2010). The present study was conducted to determine the effect of Black Cumin, Curcuma zeodharia,Curcuma mangga, and Curcuma aeruginosa on milk yield, milk quality (fat, protein, lactosa) and test of subclinical mastitis in mastitis dairy cows.

\section{MATERIALS AND METHODS}

Twenty Fries Holland lactating cows suspected mastitis subclinical (++) and positive containing bacterial pathogens (Staphylococcus, Streptococcus, E.coli, and Corynecbacterium) were used in the experiment. These cattle were in $2^{\text {nd }}-4^{\text {th }}$ lactation period, with body weight of 350 $\mathrm{kg}$ and milk production of $10-12$ liters/head/day. The experiment was done in smallholder dairy farm in Sumedang, West Java for three months. The cow were kept in individual stall equipped with feeder and waterer. They were fed 40 $\mathrm{kg} / \mathrm{head} /$ day of King grass and $6 \mathrm{~kg} / \mathrm{head} /$ day of concentrate feed produced by Koperasi Penghasil Susu-Bandung Utara (KPS-BU). The feed contained $87.07 \%$ dry matter, $12.42 \%$ crude protein and $68.00 \% \mathrm{TDN}$.

Completely randomized design was used in this experiment with 5 treatments of herbs (A. Non herb; B. $0.03 \%$ body weight of Black Cumin; C. $0.02 \%$ body weight of Curcuma zeodharia; D. $0.06 \%$ body weight of Curcuma mangga, and E. $0.02 \%$ body weight of Curcuma aeruginosa) and each treatment was repeated 4 times.

The collected data were analyzed by analysis of variance. After a significant $F$ test $(\mathrm{P}<0.05)$,
Duncan's Multiple Range Test was used to inspect differences among treatments (Gaspersz, 1995). Parameters measured were milk yield $4 \% \mathrm{FCM}$ $(\mathrm{L})$, milk fat (\%), milk protein (\%), milk lactose (\%) and the mastitis status was measured by IPB1 reagent (indirect method of mastitis) (Sudarwanto and Sudarnika, 2008).

\section{RESULTS AND DISCUSSION}

Consumer demand developed principles for organic animal husbandry that include high levels of animal welfare. Therefore, it is necessary to find a replacement alternative antibiotics with natural antioxidants commonly found in. herb. This is being achieved through keeping animals as close as possible to their natural habitat (e.g. access to grass and rangelands for maximum periods), reducing housing times and intensities, and a reducing reliance on chemo-therapy (Thamsborg and Roepstorff, 2003).

In this research, supplementation of herbs did not influence feed consumption, because the doses of herbs given were about 0.02\%-0.06\% body weight or $1 \%-2 \%$ of consentrate. Nutrients of dairy cow's requirements are $14.10 \%$ of dry matter, $1.67 \%$ of crude protein and $8.71 \%$ of TDN (Table 1.)

The milk yield at $4 \%$ FCM, milk fat, milk protein, milk lactose and mastitis status can be seen in Table 2 and Figure 1. The result indicated that Black Cumin and Curcuma aeruginosa had a highly significant effect to increase milk yield $(\mathrm{P}<0.01)$. The quality of milk in this research fulfilled the quality standards of fresh milk specified by SNI (1998). The result showed that treatments $\mathrm{D}$ and $\mathrm{E}$ had a significant effect to decrease milk protein and decrease mastitis status $(\mathrm{P}<0.05)$ and the treatments had significant effect to decrease milk fat $(\mathrm{P}>0.05)$. Treatment $\mathrm{B}$ (799.5 L) and E (815.29 L) increased milk yield by $2.83 \%-4.86 \%$ compared to control A $(777.52 \mathrm{~L})$. Treatment C $(789.98 \mathrm{~L})$ and treatment D $(785.45$ L) did not differ significantly with treatment $\mathrm{A}$ $(777.52 \mathrm{~L})$. The treatments B to E decreased milk protein compared to treatment A until 23.89\%. Treatment E (4.50\%) decreased milk lactose compared to treatment A (4.97\%), B (4.66\%), C $(4.91 \%)$, and D (5.08\%) until 9.32\%. Milk fat in this research is about $3.41 \%-3.58 \%$.

The treatment with supplementation of herbs (Black Cumin, Curcuma zeodharia, Curcuma mangga, and Curcuma aeruginosa) probably could be attributed by balance change of 
Table 1. Composition of Feed (\%)

\begin{tabular}{lccccc}
\hline & $\begin{array}{c}\text { Forage } \\
(\%)\end{array}$ & $\begin{array}{c}\text { Concentrate } \\
(\%)\end{array}$ & $\begin{array}{c}\text { Forage } \\
(40 \mathrm{~kg})\end{array}$ & $\begin{array}{c}\text { Concentrate } \\
(6 \mathrm{~kg})\end{array}$ & $\begin{array}{c}\text { Total } \\
(\mathrm{kg})\end{array}$ \\
\hline Dry matter & 19.68 & 87.07 & 7.87 & 5.24 & 13.11 \\
Ash & 16.28 & 9.30 & 1.28 & 0.49 & 1.77 \\
Crude protein & 14.87 & 12.42 & 1.17 & 0.65 & 1.82 \\
Crude fiber & 21.54 & 2.27 & 1.69 & 0.12 & 1.81 \\
Crude fat & 4.07 & 14.32 & 0.32 & 0.75 & 1.07 \\
TDN & 53.60 & 68.00 & 4.22 & 3.56 & 7.78 \\
NFE & 49.91 & 48.76 & 3.93 & 2.56 & 6.49 \\
\hline
\end{tabular}

Table 2. Milk yield, Milk Fat, Milk Protein and Milk Lactose

\begin{tabular}{ccccc}
\hline Treatments & $\begin{array}{c}\text { Milk yield 4\%FCM } \\
\text { (litres) }\end{array}$ & $\begin{array}{c}\text { Milk Fat } \\
(\%)\end{array}$ & $\begin{array}{c}\text { Milk Protein } \\
(\%)\end{array}$ & $\begin{array}{c}\text { Milk Lactose } \\
(\%)\end{array}$ \\
\hline A & $777.52^{\mathrm{a}}$ & 3.58 & $3.16^{\mathrm{a}}$ & $4.97^{\mathrm{a}}$ \\
B & $799.50^{\mathrm{b}}$ & 3.43 & $2.56^{\mathrm{b}}$ & $4.66^{\mathrm{a}}$ \\
C & $789.98^{\mathrm{a}}$ & 3.41 & $2.71^{\mathrm{b}}$ & $4.91^{\mathrm{a}}$ \\
D & $785.45^{\mathrm{a}}$ & 3.47 & $2.79^{\mathrm{b}}$ & $5.08^{\mathrm{b}}$ \\
E & $815.29^{\mathrm{c}}$ & 3.53 & $2.78^{\mathrm{b}}$ & $4.50^{\mathrm{c}}$ \\
\hline
\end{tabular}

Different superscript in same column indicates differ significantly $(\mathrm{P}<0.05)$

A. Control; B. Black cumin ( $0.03 \%$ of body weight); C. Curcuma zeodharia ( $0.2 \%$ of body weight); D. Curcuma aeruginosa ( $0.03 \%$ of body weight) ; E. Curcuma mangga ( $0.06 \%$ of body weight)

microbe in rumen. Characteristic of antioxidant was beneficial in certain doses and when given in higher doses were as antibacteria. Herbs contains saponin wich can assist in balacing microbe in rumen with depressing number of microbes with pathogenic potential. This condition causes the optimum $\mathrm{pH}$ of rumen fluid. These conditions form a better rumen ecology and the results of invitro experiment for rumen bacteria, $\mathrm{NH} 3$ concentration and volatille fatty acid on this treatment give the best results (Nurdin and Arief, 2009; Nurdin, 2010). Good ruminant nutrition depends on two factors: Vollatile Fatty Acid (VFA) and a large microorganism population in the rumen. A large microorganism population is responsible to increase VFA production (acetic acid and propionic acid). Acetic acid is function to milk fat precursor and propionic acid is function for glucose syntesis (Kalscheur et al., 2006; Wang et al., 2006). In addition, the condition of rumen ecology influence quality and quantity dairy cows production (Kay et al., 2005; Wu and Satter, 2000; Nurdin and Arief, 2009).

Black Cumin, Curcuma zeodharia, Curcuma mangga, and Curcuma aeruginosa by virtue of its antioxidant compound and anti-inflammation potential can increase alveolar cell permeability and can assist in rumen ecological balance. Herb was an antioxidant. Nurdin (2010) reported that feeding of Black Cumin, Curcuma zeodharia, Curcuma mangga, and Curcuma aeruginosa will help in establishing better conditions of rumen ecology. As a result, number of rumen bacteria and total VFA will increase and followed by reduction of $\mathrm{NH} 3$ concentration. A large microorganism population is responsible for increased VFA production. When this population increased, it results in the presence of a greater production of milk or meat (Kalscheur et al., 2006; Wang et al., 2006). 


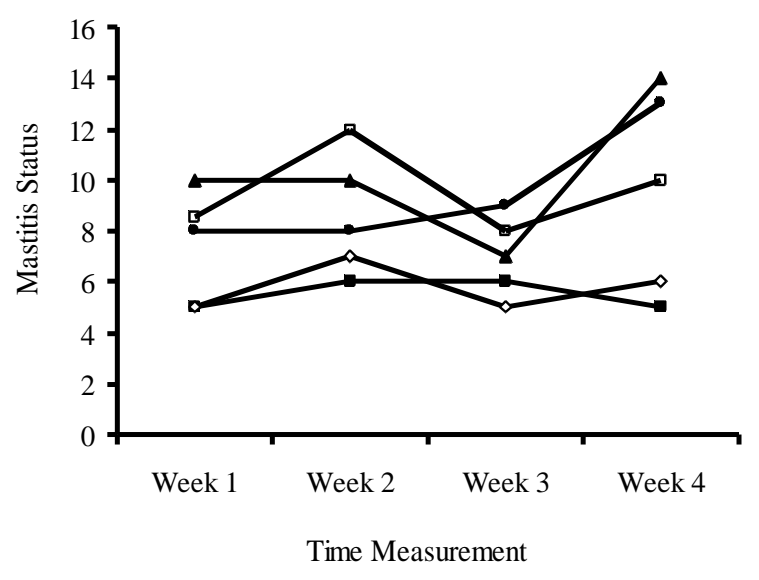

Figure 1. Condition of Mastitis Status. A. Control ( $\square$ ); B. Black cumin $(\diamond)$; C. Curcuma zeodharia ( $\square)$; D. Curcuma aeruginosa $(\mathbf{\Delta})$; E. Curcuma mangga $(\bullet)$

Minimum standard of milk quality in Indonesia for milk fat percentage is at least $3 \%$, milk protein percentage is at least $2.7 \%$, and milk lactose is $4.1 \%$ (SNI, 1998). All of the treatments did not affect milk fat because all of the dairy cow had the same managements. Milk protein with herbs had normal condition percentage of milk protein $(2.56 \%-2.79 \%)$ compared to those of without herb supplement (3.16\%). It means that there was an improvement condition because mastitis dairy cows had high milk protein compare to normal cows (Sudarwanto et al., 2006). The result showed milk protein with supplement non herbs $3.16 \%$ and milk protein with supplementation of herb for Black Cumin was $2.56 \%$, Curcuma zeodharia was $2.71 \%$, Curcuma mangga was $2.78 \%$, and Curcuma aeruginosa was $2.79 \%$ and mastitis status for non herb was 5.50 and treatment with herb was 9.510.25 .

The greater value of mastitis status showed good condition because the more healthy dairy cows (rating the status of mastitis: negatif $=4 ;+=$ $3 ;++=2 ;+++=1$; and $++++=0$ ). Mastitis condition in this research showed a decrease in the level of mastitis compared to control. Test of pathogenic bacteria conducted at the beginning and the end of research showed that all treatments contained pathogenic bacteria. This is possible because the cow's used in this research were detected positif mastitis (++) and supported by microbiologic test found pathogenic bacteria in milk. But supplementation of herbs resulted in the decrease of mastitis.

The result of this research showed that supplementation of herbs significantly $(\mathrm{P}<0.01)$ influenced mastitis status (Figure 1.) Treatment D, $\mathrm{E}$ and $\mathrm{C}$ (14, 13 and 10 status) significantly decreased the mastitis status compared to treatment A 72.73\%-86.37\%; and treatment B (6 status) did not significantly decrease their number compared to treatment A (5 status). Treatment D (Curcuma aerogenosa), E (Curcuma mangga) and C (Curcuma zeodharia) showed that the total mastitis status were low. The dairy cattle used for this research were infected by mastitis and gave positive reaction for IPB-1 test. Feeding of supplements with Black Cumin,Curcuma zeodharia,Curcuma mangga, and Curcuma aeruginosa was associated with restoration of milk constituents to normal, and herbs can reduce cases of mastitis. This effect is caused by antioxidant and anti-inflammation compounds (alkaloid, saponin, flavanoid and triterpenoid) of Curcuma zeodharia,Curcuma mangga, and Curcuma aeruginosa which can increase permeability of alveoli cells and increase body endurance.

Supplementation of herb until 4 weeks showed that it could make improvement on mastitis status. The treatment of mastitis by using antibiotic, the new Staph. aureus infection occurred again and new intramammary infections occuring after treatment and bacteria become resistant (Owens et al., 2001). The effect of antibiotics has improved and some of them are retained in the cow's body for along time and at higher concentration (Langford et al., 2003). Antibiotic residues in livestock product was harmful to consumer health. In addition, this treatment improves milk yield and milk quality, decreased condition of mastitis in dairy cattle and cured mastitis.

\section{CONCLUSION}

Supplementation of Black Cumin, Curcuma zeodharia,Curcuma mangga, and Curcuma aeruginosa is recommend for the treatment of subclinical mastitis, to increase the milk yield and milk quality.

\section{ACKNOWLEDGMENTS}

This experiment was funded by Directorate General of Higher Education, Ministry of National Education through "Hibah Kompetitif Penelitian Sesuai Prioritas Nasional batch III", No:515/SP2H/PP/DP2M/VII/2009. 


\section{REFERENCES}

Barton, M.D. and W.S. Hart. 2001. Public Health Risks: Antibiotic Resistance. Review. AsianAust. J. Anim. Sci.14 (3):414-442.

Gaspersz, V. 1995. Tekhnik Analisis dalam Penelitian Percobaan. Tarsito, Bandung.

Gravert, H.O. 1987. Dairy Catlle Production. Institute for Milk Production. Federal Dairy Research Centre Kiel FRG. Elsevier Sci. Publ. B.V. New York.

Harmon, R. J. 1994. Physiology of mastitis and factors affecting somatic cell counts. J. Dairy Sci. 77:2103-2112.

Kalscheur K.F., R.L. Baldwinvi, B.P. Glenn and R.A. Kohn. 2006. Milk production of dairy cows differing concentration of rumendegraded protein. J. Dairy Sci. 89: 249 - 259.

Kay, J.K., J.R. Roche, E.S. Kolver, N.A. Thomson and L.H. Baumgard. 2005. A comparison between feeding system (pasture and TMR) and the effect of vitamin E supplemntation on plasma and milk fatty acid profiles in dairy cows. J. Dairy Res. 72:322-332.

Lacobellis, N. S., P. L. Cantore, F. Capasso, and F. Senatore. 2005. Antibacterial Activity of Cuminum cyminum $L$. and Carum carvi $L$. Essential Oils. J. Agric. Food Chem. 53(1): 57-61.

Langford, F.M., D. M. Weary and L. Fisher. 2003. Antibiotic resistance in gut bacteria from dairy calves: A dose response to the level of antibiotics fed in milk. J Dairy Sci 86:39633966.

Li, R. and Z. T. Jiang. 2004. Chemical composition of the essential oil of Cuminum cyminum $L$. from China. Flavour and Fragrance J. 19(4):311-313. DOI. 10.1002/ffj. 1302

Martin, M., McCorkle, C. M. and E. Mathias. 2001. Ethnoveterinary Medicine: An Annotated Bibliography of Community Animal Healthcare. Intermediate Technology Development Group Publishing, London.

Nurdin, E. and Arief. 2009. The Effectivity of Cumin as natural-antioxidant to improve rumen ecology of mastitis dairy cow's. Jurnal
Produksi Ternak (University of Jenderal Soedirman). 11(3):114-119.

Nurdin, E. 2010. Pemanfaatan kunyit mangga (Curcuma mangga) terhadap ekologi rumen sapi perah Holstein. J. Penelitian Unja. 12(3):86-89.

Owens, W.E., S.C. Nickerson, R.L.Boddie, G.M.Tomita, and C.H.Ray. 2001. Prevalence of mastitis in dairy heifers and effectiveness of antibiotic therapy. J. Dairy Sci. 84:814817.

Shem, M.N., J.M.L. Malole, R. Machangu, L.R. Kurwijila and T. Fujihara. 2000. Incidence and cause of subclinical mastitis in dairy cows on smallholder and large scale farms in tropical area in Tanzania. Asian-Aust. J. Anim.Sci. 14(3):372-377.

Standar Nasional Indonesia (SNI). 1998. Badan Standarisasi Nasional-BSN, Jakarta.

Sudarwanto, M., H. Latif and M. Noordin. 2006. The relationship of the somatic cell counting to sub-clinical mastitis and to improve milk quality. The $1^{\text {st }}$ International AAVS Scientific Conference. Jakarta, July 12-13, 2006.

Sudarwanto, M. and E. Sudarnika. 2008. Nilai Diagnostik tes IPB mastitis dibandingkan dengan jumlah sel somatik dalam susu. Joint Meeting of the $3^{\text {rd }}$ International Meeting on Asian Zoo/Wildlife Medicine and Conservation (AZWMC). Bogor, 19-21 August, 2008

Soedono A, R.F. Rosdiana and B.S. Setiawan. 2003. Beternak Sapi Perah Secara Intensif. Agromedia Pustaka, Jakarta

Thamsborg, S.M. and A. Roepstorff. 2003. Parasite problems in organic livestock and options for control. J. Parasitol. 89:277-284.

Wang, C., J.X. Liu, Z.P. Yuan, Y.M. Mu, S.W. Zhai and H.W. Ye. 2006. Effect of level of metabolizable protein on milk production in lactating dairy cows. J. Dairy Sci. 90: 29602965.

Wu, Z. and L.D. Satter. 2000. Milk Production during the complete lactation of dairy cows fed diets containing different amount of protein. J. Dairy Sci. 83:1042-1051. 